\title{
High-throughput DNA sequencing to survey bacterial histidine and tyrosine decarboxylases in raw milk cheeses
}

\author{
Daniel J. O'Sullivan ${ }^{1,2}$, Vincenzo Fallico', Orla O'Sullivan', Paul L. H. McSweeney², Jeremiah J. Sheehan 1*, \\ Paul D. Cotter ${ }^{1,3^{*}}$ and Linda Giblin ${ }^{1}$
}

\begin{abstract}
Background: The aim of this study was to employ high-throughput DNA sequencing to assess the incidence of bacteria with biogenic amine (BA; histamine and tyramine) producing potential from among 10 different cheeses varieties. To facilitate this, a diagnostic approach using degenerate PCR primer pairs that were previously designed to amplify segments of the histidine (hdc) and tyrosine $(t d c)$ decarboxylase gene clusters were employed. In contrast to previous studies in which the decarboxylase genes of specific isolates were studied, in this instance amplifications were performed using total metagenomic DNA extracts.
\end{abstract}

Results: Amplicons were initially cloned to facilitate Sanger sequencing of individual gene fragments to ensure that a variety of $h d c$ and $t d c$ genes were present. Once this was established, high throughput DNA sequencing of these amplicons was performed to provide a more in-depth analysis of the histamine- and tyramine-producing bacteria present in the cheeses. High-throughput sequencing resulted in generation of a total of 1,563,764 sequencing reads and revealed that Lactobacillus curvatus, Enterococcus faecium and E. faecalis were the dominant species with tyramine producing potential, while $L b$. buchneri was found to be the dominant species harbouring histaminogenic potential. Commonly used cheese starter bacteria, including Streptococcus thermophilus and Lb. delbreueckii, were also identified as having biogenic amine producing potential in the cheese studied. Molecular analysis of bacterial communities was then further complemented with HPLC quantification of histamine and tyramine in the sampled cheeses.

Conclusions: In this study, high-throughput DNA sequencing successfully identified populations capable of amine production in a variety of cheeses. This approach also gave an insight into the broader hdc and tdc complement within the various cheeses. This approach can be used to detect amine producing communities not only in food matrices but also in the production environment itself.

Keywords: Biogenic amines, High-throughput sequencing, Histamine, Tyramine, Cheese microbiota, Ion PGM sequencing

\section{Background}

High-throughput sequencing (HTS) has significantly enhanced our ability to profile complex microbial ecosystems such as those in the sea [1], soil [2], gut [3] and various foods including cheese [4-7]. While most of these studies rely on amplifying regions of the bacterial $16 \mathrm{~S}$ rRNA or fungal ITS genes to study the microbial composition of these communities, it is also possible to

\footnotetext{
* Correspondence: Diarmuid.Sheehan@teagasc.ie; Paul.Cotter@teagasc.ie ${ }^{1}$ Teagasc Food Research Centre, Moorepark, Fermoy, Cork, Ireland Full list of author information is available at the end of the article
}

use HTS to sequence select non-16S based genes [8]. With reference to this, HTS-based methods are currently being explored to improve food safety by targeting specific undesirable populations/genes $[9,10]$, and the potential exists to target genes involved in biogenic amine (BA) formation. BAs are low molecular weight organic bases with biological activity produced, primarily, by decarboxylation of precursor amino acids. BAs are classified according to their chemical structures and can be aromatic (tyramine), heterocyclic (histamine and tryptamine) or aliphatic (putrescine and cadaverine) [11-14]. In eukaryotes BAs are 
generally associated with a variety of biological processes including blood pressure regulation, neurotransmission, cellular growth and allergic responses. In prokaryotes, however, BA formation is generally linked with cell survival, particularly in low $\mathrm{pH}$ conditions where it serves as a stress response mechanism. Up-regulation of decarboxylase gene expression has previously been shown to occur in the presence of the precursor amino acid and in low $\mathrm{pH}$ environments, such as those encountered in fermented foods. The amino acid/amine transporter system also acts to generate energy in the form of proton motive force, thus providing a further competitive advantage under such stress conditions $[15,16]$. Microbial BA formation is encountered in a variety of fermented foods and beverages including cheese, fish, beer, wine, meat products and fermented vegetables [17]. The most commonly occurring BAs detected in foods include histamine, tyramine, putrescine and cadaverine [18]. The accumulation of histamine and/or tyramine at high levels may produce toxicological effects including hypertension, headaches, palpitations and vomiting in certain individuals, particularly those with reduced mono/di-amine oxidase activity, due to either genetic or pharmacological reasons. The European Food Safety Authority regard histamine and tyramine as the most important BAs from a toxicological viewpoint [19]. Additionally, the presence of di-amines, such as putrescine and cadaverine, can further promote toxicological effects as they act as potentiators of histamine and tyramine toxicity by competing for detoxifying enzymes [20-24]. As the detrimental effects associated with consumption of BAs varies depending on the amine in question and the susceptibility of the individual, it is particularly difficult to set defined limits for BAs in food products [25]. Consequently, regulatory limits describing BA concentrations have yet to be established for the cheese industry. Notably, ripened cheeses are second only to fish as the most commonly implicated source of dietary BAs $[19,26,27]$, which has led to the coining of the term the "cheese reaction" [28].

BAs can be formed by a variety of cheese associated lactic acid bacteria (LAB) including Lactobacillus, Lactococcus, Streptococcus, Leuconostoc and Enterococcus $[15,17,18,23]$. Several factors are associated with the accumulation of BAs in cheese including low $\mathrm{pH}$, milk processing parameters (raw/pasteurised), the presence of amine forming species (starter or non-starter/contaminating bacteria), availability of precursor amino acids, ripening temperature/time and salt content, among other factors [29]. While the majority of cheese is produced from pasteurised milk, raw milk cheeses are also popular due to their unique flavour characterisitics [27]. High levels of secondary proteolysis as a result of starter and non-starter bacterial action, together with higher microbial load and, in many cases, long ripening times make raw milk cheeses particularly susceptible to BA formation $[13,14,27,28,30,31]$. The presence of BAs can also be used as an indicator of overall product hygiene in the form of biogenic amine indices [19].

Methods employed to detect BAs in dairy products have been extensively reviewed [15, 20, 29, 32, 33]. Essentially, detection is either direct, i.e., detection of the respective amines or indirect, i.e., based on identifying amine forming bacteria. Amine detection methods rely primarily on chromatographic techniques such as thin layer and high performance liquid chromatography (HPLC) [29]. While initial approaches for identifying responsible bacteria were based on differential chromogenic agars and enzymatic methods, more recently, molecular based methods such as DNA hybridisation, polymerase chain reaction (PCR) and quantitative (q)PCR have been used [20, 32, 34]. PCR based approaches are of particular use for establishing the aminogenic potential of various isolates from food products. In this instance, strains associated with raw materials, production equipment and, in the case of cheese, starter bacteria can be pre-emptively screened for decarboxylase biomarkers leading to a potential reduction of amines in the final product. A review published by Landete et al [20] describes several sets of PCR primers for detecting producers of the major food-associated amines [20].

In this study a range of raw milk, speciality cheeses were screened for the presence of histidine decarboxylase $(h d c)$ and tyrosine decarboxylase $(t d c)$ genes associated with the production of histamine and tyramine, respectively. Previously optimised PCR primer pairs amplifying regions of the Gram-positive $h d c$ and $t d c$ gene clusters were employed and the resultant amplicons were cloned and subjected to Sanger sequencing in order to establish that that there was sufficient heterogeneity among the decarboxylases present to merit a more detailed HTS analysis. HTS revealed the dominant and sub-dominant species with tyramine and histamine producing potential, in these raw milk cheeses. More importantly, the value of employing HTS to survey decarboxylase genes within a microbial population is established.

\section{Methods}

\section{Sample collection}

Ten speciality cheeses were purchased from a local market. Raw milk cheeses with long ripening times (324 months) were selected and divided into 2 groups (hard and semi-hard). Cheeses originated from several European countries including two Irish artisanal cheeses (A and B), Reblochon, Manchego, Morbier, Tête de Moine, Pecorino Sardo, Ossau-Iraty, Comté and Gorgonzola. Cheeses were vacuum packed and stored at $4{ }^{\circ} \mathrm{C}$ for 3 days prior to DNA extraction. Table 1 provides a description of the cheeses selected for this study. These particular cheeses were selected due to their potential to accumulate BAs and 
Table 1 Description of cheeses

\begin{tabular}{|c|c|c|c|c|c|c|c|c|}
\hline Cheese & $\begin{array}{l}\text { Milk Type } \\
\text { and Source }\end{array}$ & Age & Type & Region & Rind & $\begin{array}{l}\text { Total BA by } \\
\text { HPLC (mg/kg) }\end{array}$ & $\begin{array}{l}\text { Hdc gene } \\
\text { presence } \\
\text { by PCR }\end{array}$ & $\begin{array}{l}\text { Tdc gene } \\
\text { presence } \\
\text { by PCR }\end{array}$ \\
\hline Irish Artisanal Cheese A & Raw, Cow & $12-18$ months & Hard & Ireland & Waxed & 290.3 & $\mathrm{~N}$ & Y \\
\hline Reblochon & Raw, Cow & $4-12$ weeks & Semi-hard & France & Washed, smear ripened & 104.1 & Y & Y \\
\hline Irish Artisanal Cheese B & Raw, Cow & $12-18$ months & Hard & Ireland & Cloth bound natural & 456.6 & Y & Y \\
\hline Manchego & Raw, Sheep & $6-12$ months & Semi-hard & Spain & Waxed & 21.9 & $\mathrm{~N}$ & $\mathrm{~N}$ \\
\hline Morbier & Raw, Cow & $2-3$ months & Semi-hard & France & Natural & 736.5 & Y & $\mathrm{N}$ \\
\hline Tête de Moine & Raw, Cow & $3-6$ months & Hard & Switzerland & Washed & 131.9 & Y & Y \\
\hline Pecorino Sardo & Raw, Sheep & $6-10$ months & Hard & Italy & Natural & 134.2 & Y & Y \\
\hline Ossau-Iraty & Raw, Sheep & $3-6$ months & Semi-hard & France & Natural & 393.8 & Y & Y \\
\hline Comté & Raw, Cow & $6-12$ months & Hard & France & Natural & 13.8 & $\mathrm{~N}$ & $\mathrm{~N}$ \\
\hline Gorgonzola & Raw, Cow & $3-4$ months & Semi-hard & Italy & Natural & 34.2 & $\mathrm{~N}$ & $\mathrm{~N}$ \\
\hline
\end{tabular}

Description of cheeses including age, origin and rind type. HPLC results as well as presence of the respective decarboxylases detected by PCR are also included

are not reflective of all cheese within the respective categories.

\section{Determination of BA content of cheese}

BAs were acid extracted, derivatised and quantified, in duplicate, using the method described by Özoğul [35] with modifications for a cheese matrix. Five grams of cheese was weighed into a sterile bag containing $20 \mathrm{ml}$ $0.013 \mathrm{~N} \mathrm{H}_{2} \mathrm{SO}_{4}$. The suspension was homogenised in a stomacher (Iul Instruments, Barcelona, Spain) for $10 \mathrm{~min}$. The liquid phase was transferred to a sterile $50 \mathrm{ml}$ tube while the remaining cheese homogenate was subjected to a second acid extraction with $20 \mathrm{ml} 0.013 \mathrm{~N} \mathrm{H}_{2} \mathrm{SO}_{4}$. The liquid phases were pooled and centrifuged at $5000 \mathrm{~g}, 4{ }^{\circ} \mathrm{C}$ for $15 \mathrm{~min}$. After centrifugation, the solution was brought to a final volume of $50 \mathrm{ml}$ with $0.013 \mathrm{~N} \mathrm{H}_{2} \mathrm{SO}_{4}$. A $10 \mathrm{ml}$ aliquot was filtered using $0.2 \mu \mathrm{m}$ cellulose acetate filters (Chromacol, Welwyn Garden, Herts, UK).

Extracted BAs were then derivatised by mixing $1 \mathrm{ml}$ of each respective extract with $1 \mathrm{ml} 2 \mathrm{~N} \mathrm{NaOH}$ and $1 \mathrm{ml}$ $2 \%$ benzoyl chloride (Sigma-Aldrich, Wicklow, Ireland) in glass test tubes. The mixture was vortexed and allowed to stand for $15 \mathrm{~min}$ prior to the addition of $2 \mathrm{ml}$ saturated $\mathrm{NaCl}$. Two $\mathrm{ml}$ of diethyl ether was then added. A plastic pipette was used to transfer the top layer of the extract to a second glass test tube with a further $2 \mathrm{ml}$ diethyl ether added and the resultant top layers pooled. Diethyl ether was evaporated off using a stream of nitrogen at $45{ }^{\circ} \mathrm{C}$ for $20 \mathrm{~min}$. The BA residue was dissolved by adding $1 \mathrm{ml}$ acetonitrile.

BAs were separated using a Luna C18 RF $5 \mu \mathrm{m}, 100 \AA$ column 250 x $4.6 \mathrm{~mm}$ (Phenomenex Queens Avenue, Macclesfield, UK) and were eluted at an initial flow rate of $1.6 \mathrm{ml} / \mathrm{min}$ for $30 \mathrm{~min}$ with Acetonitrile (A) and $\mathrm{H}_{2} \mathrm{O}$ (B), using the following gradients:
$0-1 \mathrm{~min}$

$1.6 \mathrm{ml} / \mathrm{min}$

$40 \% \mathrm{~A}+60 \% \mathrm{~B}$

$1-10 \mathrm{~min}$

$1.8 \mathrm{ml} / \mathrm{min}$

$50 \% \mathrm{~A}+50 \% \mathrm{~B}$

$10-20 \mathrm{~min}$

$2.0 \mathrm{ml} / \mathrm{min}$

$60 \% \mathrm{~A}+40 \% \mathrm{~B}$

20-25 $\mathrm{min}$

$2.0 \mathrm{ml} / \mathrm{min}$

$70 \% \mathrm{~A}+30 \% \mathrm{~B}$

$25-26 \mathrm{~min}$

$1.6 \mathrm{ml} / \mathrm{min}$

$40 \% \mathrm{~A}+60 \% \mathrm{~B}$

26-30 min

$1.6 \mathrm{ml} / \mathrm{min}$

$40 \% \mathrm{~A}+60 \% \mathrm{~B}$

BAs were quantified using 5 data points on calibration curves against standard solutions of histamine $(100-2000 \mu \mathrm{g} / \mathrm{ml})$, tyramine $(5-100 \mu \mathrm{g} / \mathrm{ml})$, putrescine and cadaverine (Sigma-Aldrich, Dublin, Ireland) (Additional file 1: Table S1). Data was presented as $\mathrm{mg}$ of individual BA per $\mathrm{kg}$ of cheese.

\section{Determination of cheese $\mathrm{pH}$, salt and moisture contents}

Grated samples of each cheese were analysed for salt content [36], moisture [37] and $\mathrm{pH}$ [38] using previously described methods.

\section{DNA extraction from selected cheeses}

Five grams of each cheese was homogenised in $45 \mathrm{ml}$ of a $2 \%$ tri-sodium citrate buffer (VWR, Dublin, Ireland). Cheese homogenate was then subjected to enzymatic 
lysis using lysozyme $(1 \mathrm{mg} / \mathrm{ml})$, mutanolysin $(50 \mathrm{U} / \mathrm{ml})$ (Sigma Aldrich, Dublin, Ireland) and proteinase k (800 $\mu \mathrm{g} /$ $\mathrm{ml}$ ) and incubated at $55{ }^{\circ} \mathrm{C}$ for $30 \mathrm{~min}$ as per Quigley et al [39]. DNA was extracted using the PowerFood Microbial DNA Isolation Kit (MoBio Laboratories Inc, Carlsbad, CA USA). After extraction, DNA was concentrated via ethanol precipitation. DNA was re-suspended in $20 \mu \mathrm{l}$ TE buffer (Sigma-Aldrich, Dublin, Ireland). Quality and purity of extracted DNA was assessed using the NanoDrop 1000 Spectrophotometer (Thermo-Fisher Scientific, Wilmington, VA, USA), as per manufacturers guidelines.

\section{PCR detection of $h d c$ and $t d c$ gene fragments using selected primer sets}

PCR based detection of decarboxylase genes was achieved using primers specific for regions of the Gram-positive and Gram-negative $h d c$ operon, respectively, as well as for the $t d c$ operon. Primers for the $h d c$ operon of Grampositive bacteria comprised of a forward (HDC3 5'- GAT GGTATTGTTTCKTATGA-3') and a reverse primer (HD C4 5' CAAACACCAGCATCTTC-3') targeting a 435 bp fragment of the $h d c A$ gene [18]. Primers targeting the Gram-negative $h d c$ operon comprised of a forward (HIS2F 5'-AAYTSNTTYGAYTTYGARAARGARGT-3') and a reverse primer (HIS2-R 5'-TANGGNSANCCDATCATYT TRTGNCC-3'), and generated a 531 bp product [40]. The $t d c$ primers, comprised of a forward (TD5 '5- CAAATGG AAGAAGAAGTAGG-3') and a reverse primer (TD2 '5ACATAGTCAACCATRTTGAA-3’), amplified an 1100 bp fragment of the $t d c$ gene as described by Coton et al [24]. PCR reactions were carried out in triplicate and contained $25 \mu$ BioMix Red Master Mix (Bioline, London, UK), $1 \mu \mathrm{l}$ of each primer $\left(200 \mathrm{nmol} \mathrm{l}^{-1}\right), 5 \mu \mathrm{l}$ DNA template (standardised to $100 \mathrm{ng} \mathrm{DNA} /$ reaction) and nuclease free water to a final volume of $50 \mu \mathrm{l}$. PCR amplification was carried out using a G-Storm Thermal Cycler (Gene Technologies, Oxfordshire, UK). Amplification consisted of an initial denaturation at $95{ }^{\circ} \mathrm{C}$ for $10 \mathrm{~min}$ followed by 40 cycles of; denaturation at $95{ }^{\circ} \mathrm{C}$ for $45 \mathrm{~s}$, annealing at $48{ }^{\circ} \mathrm{C}$ for $1 \mathrm{~min}$ and extension at $72{ }^{\circ} \mathrm{C}$ for $90 \mathrm{~s}$. This was followed by a final elongation step at $72{ }^{\circ} \mathrm{C}$ for $7 \mathrm{~min}$. PCR amplicons were pooled and cleaned using the AMPure XP magnetic bead-based purification system (Beckman Coulter, Takeley, UK).

\section{Cloning of PCR amplicons}

Cleaned PCR amplicons were subjected to TOPO cloning reactions using the TOPO TA cloning kit (Invitrogen, CA, USA). TOP10 E. coli (Invitrogen) were transformed with the resultant plasmids and plated on LB agar (Merck) containing $50 \mu \mathrm{g} / \mathrm{ml}$ kanamycin (Sigma Aldrich, Dublin, Ireland). Transformants were selected from each cloning reaction and cultured overnight in LB broth and $50 \mu \mathrm{g} / \mathrm{ml}$ kanamycin. Plasmids were then extracted from overnight cultures using the QIAprep Spin Mini Prep kit (Qiagen, Crawley, Sussex, UK) according to the manufacturer's guidelines. Extracted plasmids were quantified and assessed for quality using the NanoDrop 1000 Spectrophotometer (Thermo-Fisher Scientific, Wilmington, VA, USA) prior to Sanger sequencing (Source BioSciences, Dublin, Ireland). The $h d c$ amplicons were sequenced using the M13 forward primer while $t d c$ amplicons were sequenced using both the M13 forward and reverse primers supplied with the TOPO TA cloning kit.

\section{High throughput sequencing}

Prior to HTS, $t d c$ amplicon libraries were prepared using the Ion Xpress Plus Fragment Library Kit (Life Technologies, Dublin, Ireland). The $h d c$ libraries, for which fragmentation was not required, were prepared using the Ion Plus Fragment Library Kit (Life Technologies, Dublin, Ireland). Libraries were then barcoded, prior to sequencing, using the Ion Xpress Barcode Adaptors (Life Technologies, Dublin, Ireland). Amplicons libraries were assessed for size distribution and concentration using a Bioanalyser 2100 (Agilent Technologies, Santa Clara, CA USA). Following library quantification and equimolar pooling, the Ion OneTouch 2 system was used to prepare template positive Ion Sphere Particles (ISP) containing the clonally amplified DNA libraries using the Ion PGM Template OT2 400 kit which allows for $<400 \mathrm{bp}$ reads. Enrichment of the template positive ISP's was performed using the Ion OneTouch ES. An enrichment percentage of $18 \%$ was obtained. Sequencing was performed on the Ion Torrent PGM (Life Technologies, Dublin, Ireland) using an Ion 318v2 chip and the Ion PGM Sequencing 400 kit (Life Technologies, Dublin, Ireland) at the Teagasc Next Generation Sequencing suite as per the manufacturer's guidelines.

\section{Bioinformatic analysis}

Following Sanger sequencing, $h d c$ reads were analysed using the NCBI nucleotide database (BlastN; http://blast.ncbi.nlm.nih.gov/). Sanger sequencing of the $t d c$ amplicons did not provide forward and reverse reads of the complete $1100 \mathrm{bp}$, therefore, only the overlap (approximately $800 \mathrm{bp}$ ), aligned using the MegAlign programme was analysed using the BlastN database.

Raw Ion PGM reads were quality filtered with the fastq_filter script in USEARCH. For both $t d c$ and $h d c$ amplicons, a length cut-off of 170 bp was used. Reads were then clustered into operational taxonomical units (OTUs) and chimeras removed with the 64-bit version of USEARCH [41]. Subsequently OTUs were aligned with MUSCLE [42] and a phylogenetic tree generated within Qiime [43]. Alpha diversity analysis was also implemented within Qiime. For taxonomic assignment OTUs were blasted against the NCBI-Nr database and parsed through MEGAN [44]. 


\section{Results}

This study used previously published PCR primers, designed based on alignments of conserved regions of decarboxylase gene clusters from known BA producing isolates [20]. In order to be sure that the variety of decarboxylase genes within the selected cheeses was sufficiently heterogeneous to merit culture-independent HTS analysis, an initial Sanger sequencing-based investigation of cloned PCR amplicons was undertaken. This was then followed by HTS to profile the dominant and subdominant histamine and tyramine producing populations present in the respective cheeses.

\section{Sanger sequencing reveals the identity of bacteria with histaminogenic potential}

The selected $h d c$ primers targeted a $435 \mathrm{bp}$ fragment of the Gram-positive $h d c A$ gene. Six of the 10 cheeses sampled generated PCR amplicons corresponding to the $h d c$ operon (Reblochon, Irish artisanal cheese B, Morbier, Tête de Moine, Pecorino Sardo, Ossau-Iraty). No amplicons were generated, across all cheese varieties, when using the selected Gram-negative $h d c$ primers [20]. The Gram-positive $h d c$ amplicons were cloned via the TOPO TA cloning method and a subset of 46 clones were subjected to Sanger sequencing. Table 2 contains a summary of BLAST output for each cheese sample while Additional file 1: Table S2 contains a complete BLAST analysis of each respective cheese including scores generated, query cover and accession numbers. BLAST output indicated that 35 of the 46 clones sequenced (76.1\%) contained a $h d c$ fragment corresponding to the Lactobacillus buchneri $h d c$ operon. Other $h d c$ sequences identified corresponded to the $h d c$ operon that is conserved across Lactobacillus sakei/Tetragenococcus halophilus/T. muriaticus/Oenococcus oeni/Lactobacillus hilgardii hdc operon (hereafter referred to as the $L b$. sakei group of $h d c$ operon; $23.4 \%)$. In the Reblochon and Tête de Moine cheeses, all of the sequenced $h d c$ clones ( 8 and 8 , respectively) corresponded to the Lb. buchneri hdc operon. In the OssauIraty cheese all of the $h d c$ positive clones were identified as corresponding to the $h d c$ operon of the $L b$. sakei group. The $h d c$ genes from Lb. buchneri and the Lb. sakei group were identified from among the Irish artisanal cheese B, Morbier and Pecorino Sardo cheeses while clones corresponding to the $L b$. sakei group $h d c$ operon were identified from among the Ossau-Iraty cheese.

\section{Sanger sequencing reveals the identity of bacteria with tyraminogenic potential}

PCR amplification, using primers designed based on alignments of tyrosine decarboxylases from known producers [20], detected the presence of an $1100 \mathrm{bp}$ fragment of the $t d c$ gene in 6 of the 10 cheeses tested (Irish artisanal cheese A, Reblochon, Irish artisanal cheese B, Tête de Moine, Pecorino Sardo, Ossau-Iraty). Table 3 depicts a summary of the BLAST output for each positive cheese samples while Additional file 1: Table S3 contains a complete BLAST analysis of samples including top hits, scores generated, query cover and accession numbers. Resultant amplicons were cloned and subjected to Sanger sequencing. In this instance, a subset of 44 clones was sequenced across the six positive cheese types. BLAST analysis revealed the presence of $t d c$ fragments corresponding to several species, including Enterococcus faecalis which

Table 2 Summary of histidine decarboxylase BLAST analysis

\begin{tabular}{|c|c|c|c|c|}
\hline Cheese & $\begin{array}{l}\text { \# of } \\
\text { Clones }\end{array}$ & BLAST output & E-value & $\%$ Identity \\
\hline Reblochon & 8 & $\begin{array}{l}\text { Lb. buchneri histidine decarboxylase operon (hdcA gene, hdcB gene, } \\
\text { hdcC gene and hisS gene) }\end{array}$ & 0 & $99 \%$ \\
\hline \multirow[t]{2}{*}{ Irish Artisanal Cheese B } & 5 & $\begin{array}{l}\text { Lb. buchneri histidine decarboxylase operon (hdcA gene, hdcB gene, } \\
\text { hdcC gene and hisS gene) }\end{array}$ & 0 & $99 \%$ \\
\hline & 1 & $\begin{array}{l}\text { Lb.sakei hdc gene, partial cds/T. halophilus hdc operon/T. muriaticus phdc/O. } \\
\text { oeni hdc operon/Lb. hilgardii hdc operon }\end{array}$ & 0 & $99 \%$ \\
\hline \multirow[t]{2}{*}{ Morbier } & 7 & $\begin{array}{l}\text { Lb. buchneri histidine decarboxylase operon (hdcA gene, hdcB gene, hdcC } \\
\text { gene and hisS gene) }\end{array}$ & 0 & $99 \%$ \\
\hline & 1 & $\begin{array}{l}\text { Lb.sakei hdc gene, partial cds/T. halophilus hdc operon/T. muriaticus phdc/O. } \\
\text { oeni hdc operon/Lb. hilgardii hdc operon }\end{array}$ & 0 & $96 \%$ \\
\hline Tête De Moine & 8 & $\begin{array}{l}\text { Lb. buchneri histidine decarboxylase operon (hdcA gene, hdcB gene, hdcC } \\
\text { gene and hisS gene) }\end{array}$ & 0 & $99 \%$ \\
\hline \multirow[t]{2}{*}{ Pecorino Sardo } & 7 & $\begin{array}{l}\text { Lb. buchneri histidine decarboxylase operon (hdcA gene, hdcB gene, hdcC } \\
\text { gene and hisS gene) }\end{array}$ & 0 & $99 \%$ \\
\hline & 1 & $\begin{array}{l}\text { Lb.sakei hdc gene, partial cds/T. halophilus hdc operon/T. muriaticus phdc/O. } \\
\text { oeni hdc operon/Lb. hilgardii hdc operon }\end{array}$ & 0 & $99 \%$ \\
\hline Ossau-Iraty & 8 & $\begin{array}{l}\text { Lb.sakei hdc gene, partial cds/T. halophilus hdc operon/T. muriaticus phdc/O. } \\
\text { oeni hdc operon/Lb. hilgardii hdc operon }\end{array}$ & 0 & $99 \%$ \\
\hline
\end{tabular}


Table 3 Summary of tyrosine decarboxylase BLAST analysis

\begin{tabular}{|c|c|c|c|c|c|}
\hline Cheese & \# of Clones & Gene target & BLAST output & E-value & $\%$ Identity \\
\hline \multirow[t]{3}{*}{ Irish Artisanal Cheese A } & 5 & $t d c$ & E. faecalis tdc operon complete cds & 0 & $99 \%$ \\
\hline & 1 & $t d c$ & E. faecalis $t d c$ operon complete cds & 1.0E-141 & $99 \%$ \\
\hline & 2 & $t d c$ & Lb. curvatus $t d c$ complete $c d s / S$. thermophilus $t d c A$ gene & 0 & $99 \%$ \\
\hline \multirow[t]{2}{*}{ Reblochon } & 5 & $t d c$ & Lb. curvatus $t d c / S$. thermophilus $t d c A$ gene complete $c d s$ & 0 & $99 \%$ \\
\hline & 1 & $t d c$ & E. faecalis tdc gene, complete cds & 0 & $100 \%$ \\
\hline Irish Artisanal Cheese B & 8 & $t d c$ & Lb. curvatus $t d c$, complete $c d s / S$. thermophilus $t d c A$ gene & 0 & $99 \%$ \\
\hline \multirow[t]{2}{*}{ Tête de Moine } & 7 & $t d c$ & E. faecalis $t d c$ gene, complete $c d s$ & 0 & $98 \%$ \\
\hline & 1 & $t d c$ & Lb. plantarum $/ L b$. brevis tdc gene $c d s$ & 0 & $99 \%$ \\
\hline \multirow[t]{3}{*}{ Pecorino Sardo } & 6 & $t d c$ & E. faecium tyrs gene, tyrdc gene complete cds & 0 & $99 \%$ \\
\hline & 1 & $t d c$ & E. faecium tyrs gene, tyrdc gene complete cds & $2 \mathrm{E}-70$ & $79 \%$ \\
\hline & 1 & $t d c$ & E. faecium tyrs gene, tyrdc gene complete cds & 0 & $89 \%$ \\
\hline \multirow[t]{4}{*}{ Ossau-Iraty } & 2 & $t d c$ & E. faecalis, tdc gene complete cds & 0 & $98 \%$ \\
\hline & 2 & $t d c$ & E. faecalis complete genome & 0 & $97 \%$ \\
\hline & 1 & $t d c$ & E. faecalis complete genome & 0 & $99 \%$ \\
\hline & 1 & $t d c$ & Lb. curvatus $t d c$ gene complete $c d s / S$. thermophilus $t d c A$ gene & 0 & $99 \%$ \\
\hline
\end{tabular}

Summary of homologues of tyrosine decarboxylase $(t d c)$ gene fragments detected in $t d c$ positive cheeses using Sanger sequencing of cloned amplicons

accounted for 19 of the 44 clones sequenced (43.1\%). The $t d c$ fragments from Lactobacillus curvatus/Streptococcus thermophilus (which share high identity with one another; $36 \%)$, E. faecium (18\%) and Lactobacillus plantarum/brevis (which, again, are not easily distinguished; $2.3 \%$ ) were also identified across the 6 cheese types. With respect to the Pecorino Sardo cheese, all clones contained $t d c$ genes corresponding to that of and E. faecium. In contrast, $t d c$ genes corresponding to those of enterococci, streptococci and lactobacilli were detected across all other cheese varieties.

a-diversity of artisanal cheese microbiota with BA-producing potential as revealed by next generation DNA sequencing Sanger sequencing established that several cheese samples contained multiple microbial sources of decarboxylase genes. As a result it was apparent that the use of a culture-independent HTS-based approach to provide an in-depth insight into the diversity of the populations present was justified. The previously generated PCR amplicons were used for HTS sequencing ( $n=6$ for grampositive $h d c$ primers and $\mathrm{n}=6$ for $t d c$ primers). Amplicons were subjected to HTS using the Ion PGM platform, generating 938,971 $h d c$ reads and 624,793 $t d c$ reads, after quality filtering (refer to Additional file 1: Table S4 for the complete list of assigned reads/cheese). Mean read length across both $t d c$ and $h d c$ samples was $245 \mathrm{bp}$. Operational Taxonomic Unit (OTU) diversity ( $\alpha$-diversity) was calculated for both $h d c$ and $t d c$ samples and is displayed in Table 4. For $h d c \alpha$-diversity, Chao1 values, indicative of taxonomic richness, ranged from 41.75 - 90 while the
Shannon index, used to measure the overall sample diversity of Gram-positive bacteria with histamine-producing potential, ranged from 2.57 - 3.23. Irish artisanal cheese B displayed the greatest sample diversity while Tête de Moine exhibited the lowest diversity. The $h d c \alpha$-diversity was observed to be lower than that of the $t d c$ samples. For $t d c$ samples, Chao1 values ranged from 224.25 - 279.62 while the Shannon index ranged from 5.48 - 6.4. Ossau-Iraty displayed the greatest sample diversity while Irish artisanal cheese B displayed the lowest sample diversity. The phylogenetic diversity value and number of observed OTU matrices also indicated that $\alpha$-diversity was considerably greater in $t d c$ samples than $h d c$ samples.

\section{High-throughput lon PGM sequencing reveals the presence of amine forming communities in different cheese varieties}

Phylogenetic assignment of high-throughput sequence data revealed $t d c$ sequences corresponding to representatives of both the Firmicutes $(99.84-100 \%$ of all $t d c$ sequences) and Actinobacteria ( $0.16 \%$ of $t d c$ sequences) phyla. All the $h d c$ sequences belonged to the Firmicutes phylum (Additional file 1: Table S5a/b). The small proportion of $t d c$ reads assigned to the phylum Actinobacteria corresponded to the cheese Ossau-Iraty. While reads were successfully allocated at phylum level, there was an expected, progressive reduction in the numbers of assigned reads at order, genus and species levels respectively. Reads successfully allocated, at phylum, order, genus and species levels, are displayed in Figs. 1 and 2. At the order level, Lactobacillales accounted for 
Table 4 a-diversity post lon PGM sequencing in $h d c$ and $t d c$ positive cheese samples

\begin{tabular}{|c|c|c|c|c|c|}
\hline \multicolumn{6}{|l|}{ hdc a-diversity } \\
\hline Cheese & Chao1 value & Simpson value & Shannon index value & Phylogenetic diversity value & No. of observed OTU's \\
\hline Reblochon & 55 & 0.80 & 2.85 & 21.96 & 52 \\
\hline Irish Artisanal Cheese B & 90 & 0.82 & 3.23 & 27.71 & 75 \\
\hline Morbier & 57.5 & 0.76 & 2.73 & 20.38 & 57 \\
\hline Tête de Moine & 41.75 & 0.67 & 2.39 & 18.25 & 38 \\
\hline Pecorino Sardo & 69.5 & 0.75 & 2.73 & 21.66 & 67 \\
\hline Ossau-Iraty & 52 & 0.78 & 2.57 & 23.48 & 50 \\
\hline \multicolumn{6}{|l|}{ tdc a-diversity } \\
\hline Cheese & Chao1 value & Simpson value & Shannon index value & Phylogenetic diversity value & No. of observed OTU's \\
\hline Irish Artisanal Cheese A & 249.06 & 0.98 & 6.40 & 145.48 & 246 \\
\hline Reblochon & 247.96 & 0.97 & 5.48 & 143.93 & 225 \\
\hline Irish Artisanal Cheese B & 224.25 & 0.97 & 5.51 & 126.47 & 188 \\
\hline Tête de Moine & 273.50 & 0.97 & 5.78 & 171.53 & 270 \\
\hline Pecorino Sardo & 270.18 & 0.97 & 5.81 & 152.71 & 259 \\
\hline Ossau-Iraty & 279.62 & 0.98 & 5.96 & 150.62 & 256 \\
\hline
\end{tabular}

a-diversity of artisanal cheeses post lon PGM sequencing. Table 4a details diversity of $h d c$ positive samples while Table $4 \mathrm{~b}$ presents tdc positive samples

33.14 - $95.11 \%$ of reads assigned in the $t d c$ samples. The Actinobacteria-assigned $t d c$ reads in Ossau-Iraty corresponded to Actinomycetales at the order level and to Micrococcinaeae at family level but could not be assigned at the genus level. With respect to the $h d c$ samples, Lactobacillales accounted for 13.7 - $42.3 \%$ of the reads assigned at the order level.

At the genus and species levels, the numbers of reads that could be unambiguously assigned was low in all cases (depicted in Additional file 1: Table S4) and this was particularly evident when analysing the $h d c$ samples. With respect to hdc samples, Lactobacillus accounted for $62.5 \%$ to $100 \%$ of all reads assigned at the genus level. Populations corresponding to Staphylococcus (37.5\% of reads assigned at genus level) were present in Irish artisanal cheese B, while Streptococcus (6.93\% of reads assigned at genus level) was identified in the Pecorino Sardo cheese. At the species level, a small cohort of the Staphylococcus population was identified as S. saprophyticus (5.97\% of reads successfully assigned at species level) while Streptococcus populations were successfully classified as $S$. thermophilus (6.94\% of reads successfully assigned at species level). Lb. buchneri accounted for the majority of reads assigned (93.06 - $100 \%)$ at species level and was detected across all cheeses except for Ossau-Iraty (Fig. 1). With respect to the Ossau-Iraty cheese, no genus or species level assignment was possible.

For the $t d c$ samples, reads were assigned primarily to the genus Enterococcus and ranged from 7.67 - $99.65 \%$ of reads assigned at genus level. Lactobacillus populations were also present and accounted for 0.35 - $92.33 \%$ of reads assigned at genus level. At the species level, $E$. faecalis accounted for the majority $(2.29$ - $100 \%)$ of reads successfully assigned at species level. Other subdominant populations identified included E. faecium, Lb. curvatus, Lb. brevis and Lb. delbrueckii (Fig. 2). Percentage populations of reads assigned exclusively at genus and species levels are shown in Additional file 1: Table S6.

\section{Cheese characterisation}

BAs were detected, at various concentrations, in all cheeses sampled and were found to range from 13.8 $736.5 \mathrm{mg} / \mathrm{kg}$ (Table 5). The average histamine content of the positive samples was $34.48 \mathrm{mg} / \mathrm{kg}$ while the average tyramine concentration was $108.69 \mathrm{mg} / \mathrm{kg}$. In all cases more than one BA was present in the cheeses sampled. Although not as toxicologically important as histamine and tyramine, putrescine and cadaverine levels were also measured to give a total BA concentration in each cheese. As expected, tyramine, generally regarded as the most common BA present in cheese $[16,19]$, was present in 9 cheese samples at concentrations ranging from 4.5 to $323.4 \mathrm{mg} /$ $\mathrm{kg}$. Histamine was present in 8 cheeses $(8.4-85.1 \mathrm{mg} / \mathrm{kg})$. Cadaverine was detected in all cheese samples at concentrations ranging from $1.2-267.4 \mathrm{mg} / \mathrm{kg}$, while putrescine was detected in 7 cheeses $(3.9-212.7 \mathrm{mg} / \mathrm{kg})$. The presence or concentration of BAs in the respective cheeses did not appear to be influenced by milk type, source or age. The Morbier cheese contained the highest concentration of total BAs $(736.5 \mathrm{mg} / \mathrm{kg})$ while the Comté cheese contained only $13.8 \mathrm{mg} / \mathrm{kg}$ total BAs. Histamine was not detected by HPLC in the Manchego and Comté cheeses. Similarly, tyramine was not detected in the Gorgonzola cheese by HPLC. 


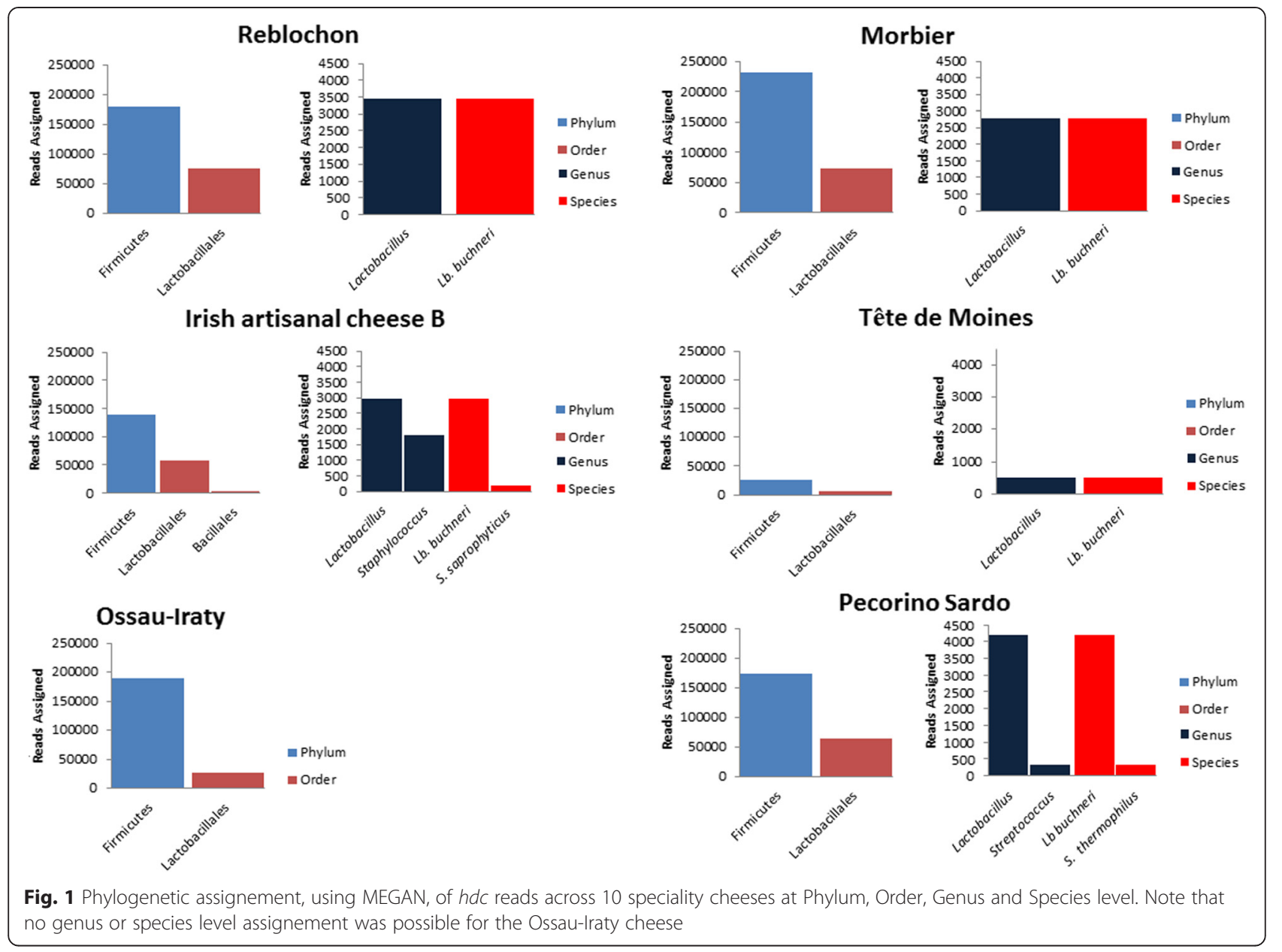

Compositional analyses of the cheeses are presented in Table 6. Salt concentrations ranged from $0.65-1.99 \%$, while cheese $\mathrm{pH}$ values extended from 5.3 to 7.1. Cheese salt in moisture levels ranged from 2.1 to 6.48 .

\section{Discussion}

In this study, a novel, targeted sequencing-based approach was used to screen a range of different cheese varieties for the presence of microbial populations capable of producing the major toxic BAs histamine and tyramine. Initially, Sanger sequencing identified common BA producers (Lb. buchneri, E. faecium and E. faecalis) $[23,45]$ but more importantly provided proof of heterogeneity justifying the use of NGS. The longer read lengths associated with the Sanger approach (up to approximately $800 \mathrm{bp}$ in the case of the $t d c$ amplicon) also allowed, in certain instances, successful identification at genus and species levels. However, the highly conserved nature of decarboxylase genes often reduced the capacity for distinguishing between certain species. This was particularly evident with respect the $L b$. sakei/T. halophilus/T. muriaticus/O.oeni/Lb. hilgardii hdc operons and the Lb. curvatus/S. thermophilus and Lb. plantarum/Lb. brevis $t d c$ operons identified. In the aforementioned cases, when conducting a BLAST analysis, the query cover and \% identity are identical while the maximum scores differ slightly. This is as a result of single nucleotide changes in the analysed sequences (described in Additional file 1: Tables S2 and S3). In the case of the Lb. curvatus/S. thermophilus $t d c$ operons identified, it likely that both of these cheese associated species are present within the samples tested. With respect to the difficulty differentiating Lb. sakei/T. halophilus/T. muriaticus/O. oeni/Lb. hilgardii hdc operons, it is difficult to predict the exact species present.

A further 1,563,764 sequence reads were generated by high-throughput DNA sequencing of amplicons (post quality filtering). HTS allowed for greater population coverage but, in many cases, the short read length led to reduced resolution. Decarboxylases from common BA producers such as E. faecalis, Lb. buchneri, Lb. brevis, and $L b$. curvatus were again identified. Subdominant populations, for example Staphylococcus saprophyticus and Lactobacillus delbrueckii, which were not observed via Sanger sequencing, were also present at less than $1 \%$ of total reads. The shorter read lengths (mean read 


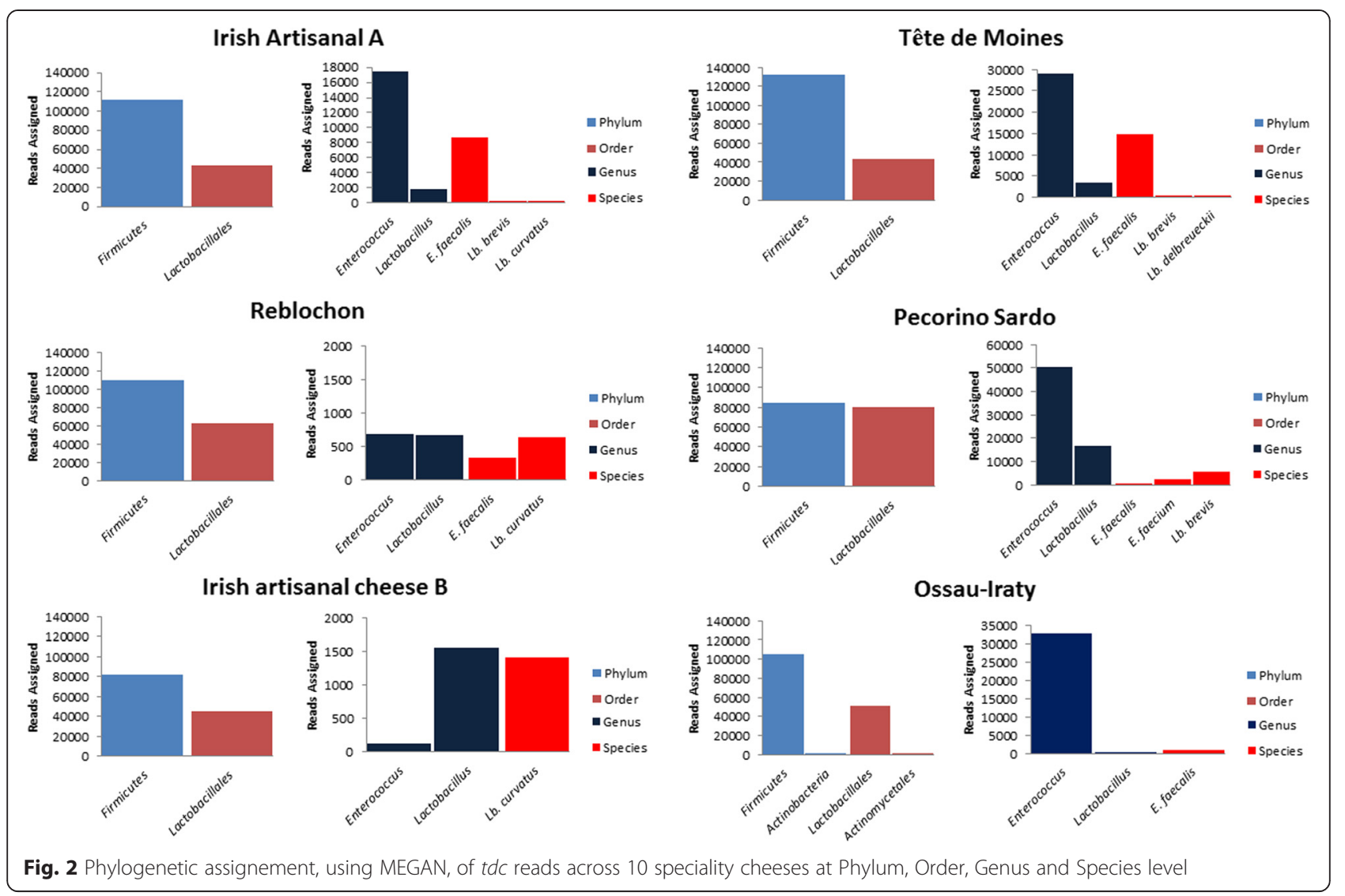

length of $245 \mathrm{bp}$ ) associated with using high-throughput sequencing, meant that, in some cases, the assignment of reads at genus and species levels was challenging (Figs. 1 and 2). This is particularly relevant with respect to the highly conserved $h d c$ operon. The absence of decarboxylase gene specific databases, as compared to the

Table 5 BA concentrations detected in cheese samples

\begin{tabular}{|c|c|c|c|c|c|}
\hline Cheese & $\begin{array}{l}\text { Histamine } \\
(\mathrm{mg} / \mathrm{kg})\end{array}$ & $\begin{array}{l}\text { Tyramine } \\
\text { (mg/kg) }\end{array}$ & $\begin{array}{l}\text { Putrescine } \\
\text { (mg/kg) }\end{array}$ & $\begin{array}{l}\text { Cadaverine } \\
(\mathrm{mg} / \mathrm{kg})\end{array}$ & $\begin{array}{l}\text { Total BA } \\
(\mathrm{mg} / \mathrm{kg})\end{array}$ \\
\hline $\begin{array}{l}\text { Irish Artisanal } \\
\text { Cheese A }\end{array}$ & 22.9 & 140.4 & 122.0 & 5.0 & 290.3 \\
\hline Reblochon & 8.4 & 45.1 & 28.2 & 22.3 & 104.1 \\
\hline $\begin{array}{l}\text { Irish Artisanal } \\
\text { Cheese B }\end{array}$ & 34.4 & 190.6 & 157.2 & 74.4 & 456.6 \\
\hline Manchego & n.d. & 17.9 & n.d. & 4.0 & 21.9 \\
\hline Morbier & 85.1 & 171.3 & 212.7 & 267.4 & 736.5 \\
\hline Tête de Moine & 51.6 & 44.6 & n.d. & 35.7 & 131.9 \\
\hline $\begin{array}{l}\text { Pecorino } \\
\text { Sardo }\end{array}$ & 23.4 & 40.4 & 66.9 & 3.5 & 134.2 \\
\hline Ossau-Iraty & 20.8 & 323.4 & 40.1 & 9.4 & 393.8 \\
\hline Comté & n.d. & 4.5 & n.d. & 9.3 & 13.8 \\
\hline Gorgonzola & 29.2 & n.d. & 3.9 & 1.2 & 34.2 \\
\hline
\end{tabular}

Average concentrations of biogenic amines ( $\mathrm{mg} / \mathrm{kg}$ of cheese) detected as determined by HPLC well annotated 16S rRNA databases, also affected the identification by BLAST analysis. Thus the combination of reduced read length and the lack of specific databases reduced the identification capacity of the HTS-based approach. This issue is particularly noticeable when analysing the microbial composition of the raw sheep milk cheese Ossau-Iraty. With reference to Ossau-Iraty, Sanger sequencing allowed for successful identification of genes assigned to E. faecalis, Lb. curvatus/S. thermophilus (both $t d c$ ), and Lb. sakei/T. halophilus/T. muriaticus/O. oeni/Lb.

Table 6 Cheese compositional analysis

\begin{tabular}{lccc}
\hline Cheese & Salt (\%) & $\mathrm{pH}$ & Salt in moisture levels \\
\hline Irish Artisanal Cheese A & 1.59 & 5.3 & 6.26 \\
Reblochon & 1.08 & 6.4 & 2.10 \\
Irish Artisanal Cheese B & 1.99 & 5.4 & 6.48 \\
Manchego & 1.44 & 5.7 & 5.24 \\
Morbier & 1.36 & 6.9 & 4.32 \\
Tête de Moine & 1.49 & 7.1 & 4.46 \\
Pecorino Sardo & 1.72 & 5.6 & 6.44 \\
Ossau-Iraty & 1.42 & 6.4 & 4.73 \\
Comté & 0.65 & 6.1 & 2.34 \\
Gorgonzola & 1.96 & 7.1 & 4.32 \\
\hline
\end{tabular}

Compositional analysis of cheeses (Salt \%, pH and Salt in Moisture) 
hilgardii ( $h d c)$, however the high-throughput approach did not permit assignment of the $h d c$ samples at the genus or species level. In the case of $t d c$ analysis, the identification of $E$. faecalis-associated $t d c$ was possible. Furthermore, while deep sequencing allowed the identification of $t d c$ genes corresponding to Actinomycetales (0.16 \%) (Fig. 2), which were assigned to the Micrococcinaeae, the shorter read length prevented assignment of these decarboxylases at genus or species levels.

HPLC results established the presence of various BAs across all cheeses sampled. However, the presence of histamine and/or tyramine did not always correlate with the presence of the corresponding decarboxylase gene fragment. This was most evident in the case of the Morbier cheese, which exhibited the highest total BA concentration in this study. Despite a tyramine concentration of $171.3 \mathrm{mg} / \mathrm{kg}$, no $t d c$ amplicons were generated by PCR. This discrepancy may be attributable to the fact that the primers selected for this study were designed to target Gram-positive LAB and were based on alignments with common (type-strains) species including Lb. sakei, $L b$. buchneri, Lactobacillus 30a, O. oeni, C. perfringens and T. muraticus ( $h d c$ ) and Lb. brevis, C. divergens, C. piscicola, E. faecalis and E. faecium $(t d c)[18,24]$. Therefore, the primers may not bind to all histamine and tyramine decarboxylase determinants present within the cheeses. Indeed, certain yeast species including strains of Y. lipolytica $(t d c)$, D. hansenii and G. candidum $(h d c)$ are recognised BA producers associated with artisanal cheeses, and may have contributed to the amine content, but would not be detected using the primers employed [13].

In this study, the identification of decarboxylase genes, using HTS, from bacteria commonly used as cheese starter cultures, including Lb. delbrueckii and S. thermophilus was of particular interest [46]. In agreement with previous reports [23, 47], S. thermophilus was identified as having histidine decarboxylation capacity in the Pecorino Sardo cheese. The origin of these bacteria, i.e., whether they were added as cheese starters or gained access to the cheese via raw milk or during processing or ripening is not known. This highlights the importance of screening starter and adjunct bacteria for aminogenic potential, using molecular methods that can rapidly detect the presence of decarboxylase genes. S. saprophyticus, not commonly associated with BA formation in cheese, was identified in this study and has previously been associated with BA formation in fermented meat products $[48,49]$.

Of the cheeses selected for this study, both PecorinoSardo and Manchego have a well-established association with BAs. In particular, Pecorino Sardo, identified in this study as containing several $h d c$ and $t d c$ positive bacteria (Lb. buchneri, E. faecium, E. faecalis), has previously been shown to contain conditions (microbiota, ripening time, physio-chemical factors) complementary to BA production [30, 50]. Manchego has also previously been shown to contain tyrosine decarboxylating microorganisms; however, in this study the Manchego cheese sampled had a low level of total BA concentrations $(21.9 \mathrm{mg} / \mathrm{kg})$ and no $t d c$ or $h d c$ positive amplicons were generated [51]. Comté and Gorgonzola have also previously been shown to contain various BAs [52] but in our study BA levels were low and no $h d c$ or $t d c$ amplicons were generated. Interestingly, blue cheeses such as Gorgonzola are often regarded as having optimal conditions for BA production, due to milk processing and proteolytic activity (presence of molds), for BA formation, however, in this study the Gorgonzola sample exhibited among the lowest total BA concentrations $[33,53]$.

\section{Conclusions}

Ultimately, this study shows, for the first time, that sequencing based technologies (Ion PGM platform) can successfully profile the diversity of histaminogenic and tyraminogenic bacteria present in ripening cheese. A similar approach could also be applied to reduce risk factors associated with BA accumulation. This can be achieved by screening starter cultures, milk and manufacturing/storage facilities with a view to reducing/controlling not only populations associated with BA formation, but potential sources of these populations [13, 54-56]. In this way, a pre-emptive approach using existing (refrigeration, preservatives, additives) and/or emerging (microbial modelling, high hydrostatic pressure, irradiation) control measures can be implemented [54, 57-60]. This method cannot, however, determine the transcriptional activity of the respective genes. In addition, while NGS reads indicate, proportionally, the levels of bacterial populations within the cheese matrix, it does not accurately quantify the numbers of bacteria present. While further optimisation is required, sequencing based approaches have the potential to eventually replace labour intensive culture-based methods which often require primary culturing followed by molecular methods to identify responsible genera.

\section{Additional file}

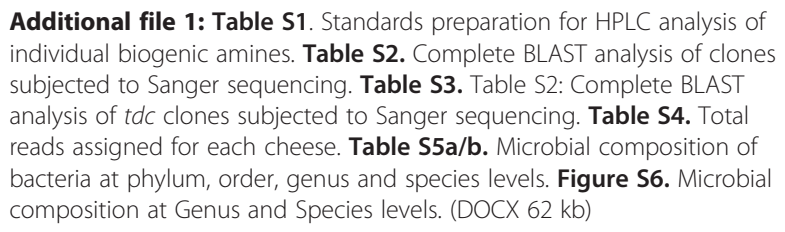

Additional file 1: Table S1. Standards preparation for HPLC analysis of individual biogenic amines. Table S2. Complete BLAST analysis of clones subjected to Sanger sequencing. Table S3. Table S2: Complete BLAST analysis of $t d c$ clones subjected to Sanger sequencing. Table S4. Total reads assigned for each cheese. Table $\mathbf{S 5 a / b}$. Microbial composition of bacteria at phylum, order, genus and species levels. Figure S6. Microbial composition at Genus and Species levels. (DOCX 62 kb)

\footnotetext{
Abbreviations

BA: Biogenic amine; DNA: Deoxyribonucleic acid; Hdc: Histidine decarboxylase gene; Tdc: Tyrosine decarboxylase gene; PCR: Polymerase chain reaction; PGM: Personal genome machine; HTS: High throughput sequencing; ITS: Internal transcribed spacer; LAB: Lactic acid bacteria;
} 
HPLC: High performance liquid chromatography; N: Normal; TE: Tris ethylenediaminetetraacetic acid; BLAST: Basic local alignment search tool; OTU: Operational taxonomic unit; Bp: Base pair.

\section{Competing interests}

The authors declare that there are no competing interests.

\section{Authors' contributions}

DO'S VF, PC and JS conceived the project. DO'S and PC designed the experiments, DO'S performed experiments, analysed the data and wrote the manuscript. VF performed BA extraction from cheese samples. OO'S performed the bioinformatic assembly. DOS, VF, PC, OOS, LG and PMCS assisted in critical appraisal of the manuscript. All authors read and approved the final manuscript.

\section{Acknowledgements}

This work was funded by the Department of Agriculture, Food and the Marine under the Food Institutional Research Measure through the 'Cheeseboard 2015' project. Daniel J. O'Sullivan is in receipt of a Teagasc Walsh Fellowship, Grant Number: 2012205. The authors would like to thank Dr. Fiona Crispie and Vicki Murray for technical assistance with respect to sample preparation for HTS sequencing and Helen Slattery for assistance with HPLC.

\section{Author details}

'Teagasc Food Research Centre, Moorepark, Fermoy, Cork, Ireland. ${ }^{2}$ School of Food and Nutritional Sciences, University College Cork, Cork, Ireland.

${ }^{3}$ Alimentary Pharmabiotic Centre, Cork, Ireland.

Received: 12 June 2015 Accepted: 2 November 2015

Published online: 17 November 2015

\section{References}

1. Sogin ML, Morrison HG, Huber JA, Welch DM, Huse SM, Neal PR, et al. Microbial diversity in the deep sea and the underexplored "rare biosphere". Proc Natl Acad Sci. 2006;103(32):12115-20. doi:10.1073/pnas.0605127103.

2. Nacke H, Thurmer A, Wollherr A, Will C, Hodac L, Herold N, et al. Pyrosequencing-based assessment of bacterial community structure along different management types in German forest and grassland soils. PLoS One. 2011;6(2):e17000. doi:10.1371/journal.pone.0017000.

3. Claesson MJ, O'Sullivan O, Wang Q, Nikkilä J, Marchesi JR, Smidt H, et al. Comparative analysis of pyrosequencing and a phylogenetic microarray for exploring microbial community structures in the human distal intestine. PLoS One. 2009;4(8):e6669. doi:10.1371/journal.pone.0006669.

4. Quigley L, O'Sullivan O, Beresford TP, Ross RP, Fitzgerald GF, Cotter PD. High-throughput sequencing for detection of subpopulations of bacteria not previously associated with artisanal cheeses. Appl Environ Microbiol. 2012;78(16):5717-23. doi:10.1128/aem.00918-12.

5. Alegría Á, Szczesny P, Mayo B, Bardowski J, Kowalczyk M. Biodiversity in Oscypek, a traditional polish cheese, determined by culture-dependent and -independent approaches. Appl Environ Microbiol. 2012;78(6):1890-8. doi:10.1128/aem.06081-11.

6. Wolfe Benjamin E, Button Julie E, Santarelli M, Dutton Rachel J. Cheese rind communities provide tractable systems for in situ and in vitro studies of microbial diversity. Cell. 2014;158(2):422-33. doi:10.1016/j.cell.2014.05.041.

7. O'Sullivan DJ, Cotter PD, Sullivan OO, Giblin L, McSweeney PLH, Sheehan JJ. Temporal and spatial differences in microbial composition during the manufacture of a Continental-type cheese. Appl Environ Microbiol. 2015 doi:10.1128/aem.04054-14.

8. Chang F, Li MM. Clinical application of amplicon-based next-generation sequencing in cancer. Cancer Genetics. 2013;206(12):413-9. http://dx.doi.org/10.1016/j.cancergen.2013.10.003.

9. Diaz-Sanchez S, Hanning I, Pendleton S, D'Souza D. Next-generation sequencing: the future of molecular genetics in poultry production and food safety. Poult Sci. 2013;92(2):562-72. doi:10.3382/ps.2012-02741.

10. Mayo B, T. C. C. Rachid C, Alegria A, M. O. Leite A, S. Peixoto R, Delgado S. Impact of next generation sequencing techniques in food microbiology. Curr Genomics. 2014;15(4):293-309.

11. Silla Santos MH. Biogenic amines: their importance in foods. Int J Food Microbiol. 1996;29(2-3):213-31.
12. Shalaby AR. Significance of biogenic amines to food safety and human health. Food Res Int. 1996;29(7):675-90.

13. Linares DM, Martin MC, Ladero V, Alvarez MA, Fernandez M. Biogenic amines in dairy products. Crit Rev Food Sci Nutr. 2011;51(7):691-703. doi:10.1080/10408398.2011.582813.

14. Novella-Rodríguez S, Veciana-Nogués MT, Izquierdo-Pulido M, Vidal-Carou MC. Distribution of biogenic amines and polyamines in cheese. J Food Sci. 2003;68(3):750-6. doi:10.1111/j.1365-2621.2003.tb08236.x.

15. Spano G, Russo P, Lonvaud-Funel A, Lucas P, Alexandre H, Grandvalet $C$, et al. Biogenic amines in fermented foods. Eur J Clin Nutr. 2010;64 Suppl 3:S95-100. doi:10.1038/ejen.2010.218.

16. Linares DM, Fernández M, Martín MC, Álvarez MA. Tyramine biosynthesis in Enterococcus durans is transcriptionally regulated by the extracellular $\mathrm{pH}$ and tyrosine concentration. J Microbial Biotechnol. 2009;2(6):625-33. doi:10.1111/j.1751-7915.2009.00117.x.

17. Burdychova $R$, Komprda T. Biogenic amine-forming microbial communities in cheese. FEMS Microbiol Lett. 2007;276(2):149-55. doi:10.1111/j.1574-6968.2007.00922.x.

18. Coton E, Coton M. Multiplex PCR for colony direct detection of Gram-positive histamine- and tyramine-producing bacteria. Journal of Microbiological Methods. 2005;63(3):296-304. http://dx.doi.org/10.1016/ j.mimet.2005.04.001.

19. EFSA Panel on Biological Hazards (BIOHAZ). Scientific Opinion on risk based control of biogenic amine formation in fermented foods. Available online: www.efsa.europa.eu/efsajournal EFSA Journal 2011;9(10):2393 [93 pp] doi:102903/jefsa20112393; 2011.

20. Landete JM, de las Rivas B, Marcobal A, Muñoz R. Molecular methods for the detection of biogenic amine-producing bacteria on foods. Int J Food Microbiol. 2007;117(3):258-69. http://dx.doi.org/10.1016/ j.i.joodmicro.2007.05.001.

21. Bunkova L, Bunka F, Mantlova G, Cablova A, Sedlacek I, Svec P, et al. The effect of ripening and storage conditions on the distribution of tyramine, putrescine and cadaverine in Edam-cheese. Food Microbiol. 2010;27(7): 880-8. doi:10.1016/j.fm.2010.04.014.

22. Ladero V, Fernández M, Alvarez MA. Effect of post-ripening processing on the histamine and histamine-producing bacteria contents of different cheeses. Int Dairy J. 2009;19(12):759-62. http://dx.doi.org/10.1016/ j.idairyj.2009.05.010.

23. Linares DM, del Río B, Ladero V, Martínez N, Fernández M, Martín MC, et al. Factors influencing biogenic amines accumulation in dairy products. Front Microbiol. 2012;3:180.

24. Coton $\mathrm{M}$, Coton $\mathrm{E}$, Lucas $\mathrm{P}$, Lonvaud A. Identification of the gene encoding a putative tyrosine decarboxylase of Carnobacterium divergens 508 . Development of molecular tools for the detection of tyramine-producing bacteria. Food Microbiol. 2004;21(2):125-30.

25. Ladero V, Calles-Enriquez M, Fernandez M, Alvarez MA. Toxicological Effects of Dietary Biogenic Amines. Curr Nutr \& Food Sci. 2010;6(2):145-56.

26. Valsamaki K, Michaelidou A, Polychroniadou A. Biogenic amine production in Feta cheese. Food Chem. 2000;71 (2):259-66. http://dx.doi.org/10.1016/ S0308-8146(00)00168-0.

27. Guarcello R, Diviccaro A, Barbera M, Giancippoli E, Settanni L, Minervini F, et al. A survey of the main technology, biochemical and microbiological features influencing the concentration of biogenic amines of twenty Apulian and Sicilian (Southern Italy) cheeses. Int Dairy J. 2015;43:61-9. http://dx.doi.org/10.1016/j.idairyj.2014.11.007.

28. Fernandez M, Linares DM, Del Rio B, Ladero V, Alvarez MA. HPLC quantification of biogenic amines in cheeses: correlation with PCR-detection of tyramine-producing microorganisms. J Dairy Res. 2007;74(3):276-82. doi:10.1017/s0022029907002488.

29. Loizzo MR, Menichini F, Picci N, Puoci F, Spizzirri UG, Restuccia D. Technological aspects and analytical determination of biogenic amines in cheese. Trends Food Sci Technol. 2013;30(1):38-55. http://dx.doi.org/10.1016/ j.tifs.2012.11.005.

30. Schirone M, Tofalo R, Fasoli G, Perpetuini G, Corsetti A, Manetta AC, et al. High content of biogenic amines in Pecorino cheeses. Food Microbiol. 2013;34(1):137-44. http://dx.doi.org/10.1016/j.fm.2012.11.022.

31. Montel M-C, Buchin S, Mallet A, Delbes-Paus C, Vuitton DA, Desmasures $N$ et al. Traditional cheeses: Rich and diverse microbiota with associated benefits. Int J Food Microbiol. 2014;177(54):136. http://dx.doi.org/10.1016/ j.jfoodmicro.2014.02.019. 
32. Marcobal A, de las Rivas B, Muñoz R. Methods for the detection of bacteria producing biogenic amines on foods: a survey. J Verbr Lebensm. 2006;1(3):187-96. doi:10.1007/s00003-006-0035-0.

33. O Sullivan D, Cotter P, Giblin L, Sheehan J, McSweeney P. Nucleic acid-based approaches to investigate microbial-related cheese quality defects. Front Microbiol. 2013;4:1. doi:10.3389/fmicb.2013.00001.

34. Ladero V, Linares DM, Fernández M, Alvarez MA. Real time quantitative PCR detection of histamine-producing lactic acid bacteria in cheese: Relation with histamine content. Food Res Int. 2008;41(10):1015-9. http://dx.doi.org/ 10.1016/j.foodres.2008.08.001.

35. Özoğul F. Production of biogenic amines by Morganella morganii, Klebsiella pneumoniae and Hafnia alvei using a rapid HPLC method. Eur Food Res Technol. 2004;219(5):465-9. doi:10.1007/s00217-004-0988-0.

36. IDF. Cheese and processed cheese: Determination of chloride content (potentiometric titration method). International Standards 4a Brussels, Belgium: International Dairy Federation; 1988.

37. IDF. Determination of total solids content (cheese and processed cheese). International Standards 4a Brussels, Belgium: International Dairy Federation; 1982.

38. Standards IB. British Standard Methods for Chemical Analysis of Cheese: Determination of pH value., vol BS 770: part 5. London: British Standards Institute; 1976.

39. Quigley L, O'Sullivan O, Beresford TP, Paul Ross R, Fitzgerald GF, Cotter PD. A comparison of methods used to extract bacterial DNA from raw milk and raw milk cheese. J Appl Microbiol. 2012;113(1):96-105. doi:10.1111/j. 1365-2672.2012.05294.x.

40. de las Rivas B, Marcobal A, Carrascosa AV, Munoz R. PCR detection of foodborne bacteria producing the biogenic amines histamine, tyramine, putrescine, and cadaverine. J Food Prot. 2006;69(10):2509-14.

41. Edgar RC. Search and clustering orders of magnitude faster than BLAST. Bioinformatics. 2010;26(19):2460-1. doi:10.1093/bioinformatics/btq461.

42. Edgar R. MUSCLE: a multiple sequence alignment method with reduced time and space complexity. BMC Bioinformatics. 2004:5(1):113.

43. Caporaso JG, Kuczynski J, Stombaugh J, Bittinger K, Bushman FD, Costello EK, et al. QIIME allows analysis of high-throughput community sequencing data. Nat Methods. 2010;7(5):335-6. doi:10.1038/nmeth.f.303.

44. Huson DH, Auch AF, Qi J, Schuster SC. MEGAN analysis of metagenomic data. Genome Res. 2007;17(3):000. doi:10.1101/gr.5969107.

45. Stratton JE, Hutkins RW, Taylor SL. Biogenic amines in cheese and other fermented foods: a review. J Food Prot. 1991;54(6):460-70.

46. Beresford TP, Fitzsimons NA, Brennan NL, Cogan TM. Recent advances in cheese microbiology. Int Dairy J. 2001;11(4):259-74. doi:10.1016/ S0958-6946(01)00056-5.

47. Rossi F, Gardini F, Rizzotti L, La Gioia F, Tabanelli G, Torriani S. Quantitative analysis of histidine decarboxylase gene (hdcA) transcription and histamine production by streptococcus thermophilus PRI60 under conditions relevant to cheese making. Appl Environ Microbiol. 2011;77(8):2817-22. doi:10.1128/ aem.02531-10.

48. Bover-Cid S, Hugas M, Izquierdo-Pulido M, Vidal-Carou MC. Amino acid-decarboxylase activity of bacteria isolated from fermented pork sausages. Int J Food Microbiol. 2001;66(3):185-9. http://dx.doi.org/10.1016/ S0168-1605(00)00526-2.

49. Santos MH. Amino acid decarboxylase capability of microorganisms isolated in Spanish fermented meat products. Int J Food Microbiol. 1998;39(3):227-30.

50. Martuscelli M, Gardini F, Torriani S, Mastrocola D, Serio A, Chaves-López C, et al. Production of biogenic amines during the ripening of Pecorino Abruzzese cheese. Int Dairy J. 2005;15(6-9):571-8.

51. Fernández-García E, Tomillo J, Núñez M. Effect of added proteinases and level of starter culture on the formation of biogenic amines in raw milk Manchego cheese. Int J Food Microbiol. 1999;52(3):189-96.

52. Mayer HK, Fiechter G, Fischer E. A new ultra-pressure liquid chromatography method for the determination of biogenic amines in cheese. J Chromatogr A. 2010;1217(19):3251-7. http://dx.doi.org/10.1016/j.chroma.2009.09.027.

53. Herrero-Fresno A, Martinez N, Sanchez-Llana E, Diaz M, Fernandez M, Martin $M C$, et al. Lactobacillus casei strains isolated from cheese reduce biogenic amine accumulation in an experimental model. Int J Food Microbiol. 2012;157(2):297-304. doi:10.1016/j.jifoodmicro.2012.06.002

54. Naila A, Flint S, Fletcher G, Bremer P, Meerdink G. Control of biogenic amines in food-existing and emerging approaches. J Food Sci. 2010;75(7):R139-50. doi:10.1111/j.1750-3841.2010.01774.x.
55. Komprda T, Smělá D, Novická K, Kalhotka L, Sustová K, Pechová P. Content and distribution of biogenic amines in Dutch-type hard cheese. Food Chem. 2007;102(1):129-37. http://dx.doi.org/10.1016/j.foodchem.2006.04.041.

56. Bokulich NA, Mills DA. Facility-specific "house" microbiome drives microbial landscapes of artisan cheesemaking plants. Appl Environ Microbiol. 2013;79(17):5214-23. doi:10.1128/AEM.00934-13.

57. Leuschner RG, Heidel M, Hammes WP. Histamine and tyramine degradation by food fermenting microorganisms. Int J Food Microbiol. 1998;39(1-2):1-10.

58. Leuschner RG, Hammes WP. Degradation of histamine and tyramine by Brevibacterium linens during surface ripening of Munster cheese. J Food Prot. 1998:61(7):874-8.

59. García-Ruiz A, González-Rompinelli EM, Bartolomé B, Moreno-Arribas MV. Potential of wine-associated lactic acid bacteria to degrade biogenic amines. Int J Food Microbiol. 2011;148(2):115-20. http://dx.doi.org/10.1016/ j.ijfoodmicro.2011.05.009.

60. Fadda S, Vignolo G, Oliver G. Tyramine degradation and tyramine/histamine production by lactic acid bacteria and Kocuria strains. Biotechnol Lett. 2001;23(24):2015-9. doi:10.1023/A:1013783030276.

\section{Submit your next manuscript to BioMed Central and take full advantage of:}

- Convenient online submission

- Thorough peer review

- No space constraints or color figure charges

- Immediate publication on acceptance

- Inclusion in PubMed, CAS, Scopus and Google Scholar

- Research which is freely available for redistribution 